\title{
Megavesícula causada por neuropatía autonómica diabética
}

\author{
Megagallblader caused by diabetic autnomic neuropathy \\ Wendy Samaniego Mojica ${ }^{1,2, a}$, Jorge Casas Castañeda ${ }^{1,2, b}$
}
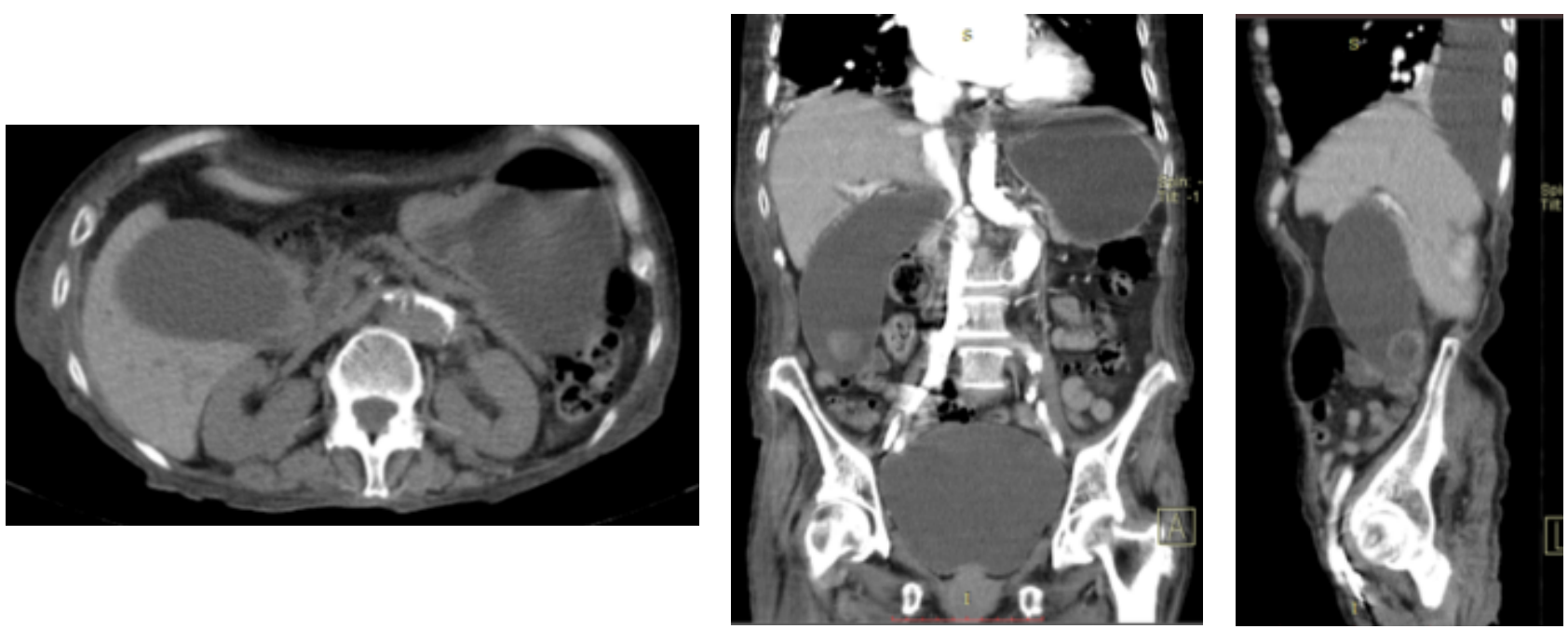

Mujer de 85 años, con diagnóstico de Diabetes Mellitus tipo II desde hace 40 años, ingresó con dolor abdominal. La Tomografía espiral multicorte (TEM) de abdomen reveló imágenes compatibles con gastroparesia diabética y vejiga neurogenica. También mostró una vesícula biliar gigante $(13 \times 6 \times 5 \mathrm{~cm})$ con un volumen similar al del hígado. El volumen normal de la vesícula biliar en ayunas es de 11 a $51 \mathrm{~cm}^{3}$, en este caso fue $221 \mathrm{~cm}^{3}$ con la fórmula para calcular el volumen de elipsoides. En neuropatía diabética autonómica se puede encontrar: Incremento del volumen, entre 3-9 veces lo normal e, hipocinesia con vaciamiento lento e incompleto. Estas anormalidades se deben a la neuropatía autonómica diabética y a una respuesta defectuosa a colecistoquinina y secretina.

An 85-year-old woman diagnosed of type II diabetes mellitus 40 years ago, was admitted with abdominal pain. The abdominal CT scan revealed images compatible with diabetic gastric paresis and neurogenic bladder, but also showed a giant gallblader measuring $13 \times 6 \times 5 \mathrm{~cm}$ with a volumen similar to the liver. Normal volume of the gallblader at fasting state is $11-51 \mathrm{~cm} 3$, but $221 \mathrm{~cm} 3$ was found in this patient. Autonomic diabetic neuropathy may produce 3-9 times increase in size of the gallblader, hipokinesis and slow or incomplete emptiness. These abnormalities are the result of an abnormal response to cholecystokinin and secretine. 